\title{
Making an Unsustainable Industry More Sustainable
}

\author{
D.V. Boger Department of Chemical and Biomolecular Engineering, University of Melbourne, Australia \\ B.C. Hart Department of Chemical and Biomolecular Engineering, University of Melbourne, Australia
}

\begin{abstract}
The minerals and energy industries are unsustainable by definition as the basic resource is finite. However, movement to more sustainable practice can be achieved by improved waste management, using current technology. The paper reviews current practice in the management of waste tailings using positive and negative examples from both the minerals and energy industries. Arguably these industries are the largest solid-liquid waste producers in the world yet many (most) fail to embrace the available technology, even to take the first step of improved dewatering and water reuse to move to a more sustainable practice. Why? Is regulation the answer? Probably not. The paper concludes that a greater rate of positive change in the waste management practice will occur in the future, motivated by a number of factors and perhaps even by common sense accounting.
\end{abstract}

\section{Introduction}

In October 2004, one of the authors (D.V. Boger) attended an Inaugural Global Sustainable Development Conference sponsored by the Minerals Council of Australia, BHP Billiton and Rio Tinto. The theme of the conference was 'Sustainability and Innovation'. The outcome of the conference was to conclude that more sustainable development in the industry can in fact lead to innovation and affect the bottom line in a positive way. What was noticeably absent in the conference was any discussion of the major amount of waste produced by this industry worldwide and any attempt to deal more effectively with this waste. Professor Doug Furstenau in a presentation at Luleå University of Technology (Sweden) in November, 2001 entitled "Challenges in energy, environment and minerals" stated that in the USA alone, which is not normally considered a major producer of minerals, two billion tonnes of dry mineral waste made up of about one third from copper, one sixth from iron ore, and one fourth from phosphate rock is produced annually. He suggested that this was ten times the amount of municipal waste produced! We estimate that at least ten billion tonnes per year on a dry basis of fine particle waste is produced by this industry worldwide. Arguably then the minerals industry is the largest producer of waste in the world. Whilst there has been significant improvement in technology available for waste management, senior management in the industry seems, or would appear to be, in denial. We have made numerous approaches to major mineral houses to present a point of view in an open forum which would suggest that the industry could improve its image by being more proactive and moving towards more sustainable practices in its handling of liquid wastes. Removal and reuse of more water would be a good first step.

There is currently an unprecedented boom in the worldwide resources industry which will be accompanied by huge expansion in general industry which will generate even more waste. And, of course, with the high demand and high price, less rich orebodies will become economically viable, which in turn will generate even more waste. It would seem appropriate at this time of staggering profits by this industry that a more pro-active (and perhaps more costly upfront) approach should be taken in dealing with this waste.

Examples of massive mining operations where huge expansions are currently taking place are in the copper industry worldwide and in the oil sands industry in northern Alberta, Canada, to name but two. In a private communication (Lord, E.R., 2002) it was estimated that by 2010 the oil sands industry will be producing about one million barrels of oil per day from surface-mined oil sands. We suspect this figure is already exceeded. One million barrels of oil per day equates to about one million $\mathrm{m}^{3}$ of coarse tailings deposit per day and 200,000-300,000 $\mathrm{m}^{3}$ of fine tailings per day. At the time of the private communication, the industry had produced 400 million $\mathrm{m}^{3}$ of fine tailings, which is stored in above ground facilities. Arguably the largest copper mine in the world is Escondida in the Atacama Desert in Chile where we believe there are current 
plans for further expansion. We believe that currently about 230,000 $\mathrm{t}$ of fine particle waste on a dry basis is produced per day by this mine and pumped at a low concentration as a Newtonian fluid to a disposal area.

\section{Examples of progress towards a more sustainable practice}

There is a growing awareness that effective tailings management is essential for creating a more sustainable mining industry. Tacey and Hart (2006) have addressed this issue. Table 1 lists an order of movement from the least sustainable to the most sustainable practice associated with the liquid suspension wastes generated in the minerals industry. The least sustainable method is direct discharge into rivers or into the sea, and of course, the most sustainable practice would be the re-use of the tailings or in fact, placing it back as a dry material into the mine from which it was extracted.

Table 1 Sustainability of tailings management practice

\begin{tabular}{ll}
\hline & Tailings Management Practice \\
\hline Least sustainable & Riverine \\
& Submarine \\
& Conventional tailings dam \\
& Central thickened discharge \\
& Dry stacking \\
& Paste backfill \\
& Re-use of tailings \\
& Dry backfill \\
\hline
\end{tabular}

\subsection{Alcoa Alumina}

Within the mining industry, the alumina industry has been most innovative in moving towards more sustainable practice. Some of the practices of this industry have been outlined in a number of publications by Dr David Cooling (Cooling, 2007). We started working with Alcoa in 1974; the work completed with the submission of Cooling's thesis in 2005 (Cooling, 2005). During this time both Alcoa and the industry in general went from pumping material at a $\mathrm{pH}$ of about 13 and at a concentration of about $15-20 \%$ to a situation where material is handled at about $50 \%$ by weight solids that has allowed them to go from wet disposal to dry stacking. The industry has not stopped at this level of improvement, taking it a step further. Cooling's thesis describes in some detail, supported with pilot plant data, how sequestering of $\mathrm{CO}_{2}$ in the caustic red mud can be used to a considerable advantage. Not only does the sequestering of the $\mathrm{CO}_{2}$ reduce the $\mathrm{pH}$, but the $\mathrm{pH}$ is reduced to a level where biological activity can take place with the residual carbon in the mud, thus producing more $\mathrm{CO}_{2}$, and perhaps in the long term even increasing the amount of alumina that can be recovered. This illustrates how more sustainable practices can positively affect the ultimate financial bottom line. The industry is looking to the re-use of the waste in the long term. The key to the alumina industry success has been compression dewatering in superthickeners, pumping non-Newtonian material at high concentrations, and understanding the rheology such that the material can be spread into drying pans, dried in the environment and then layered. This method of disposal is called "dry stacking".

The reasons for thickening should be obvious. In the Alcoa case, thickening reclaims water with a caustic reagent which also reduces potential for caustic leaks from the ponds; the increased tailings density in the storage facility minimises the facility footprint. Other industries could justify thickening to reclaim energy or to render the material suitable for mine stope backfill.

\subsection{Unsustainable practice}

At the 'least sustainable' end of the tailings management spectrum, direct riverine discharge seems to occur primarily in New Guinea and Indonesia, although we are not aware of the practices used in some countries 
such as China. The most quoted example in Australia is of course the BHP Billiton Ok Tedi mine, of which BHP Billiton no longer has any ownership. A conventional tailings dam was originally planned for tailings storage at Ok Tedi. However, two landslides in 1984 destroyed the initial foundations part way through construction (Wood et al., 2001), also resulting in loss of life (Mineral Policy Institute and AID/WATCH, 1999). The shareholders of Ok Tedi decided that mining should proceed using riverine tailings disposal as an interim measure rather than delay the project and lose investor confidence. Subsequent geotechnical studies showed that a conventional tailings dam for low concentration tailings could not be constructed safely near the mine (Wood et al., 2001). Riverine tailings disposal continues at Ok Tedi to this day. An agreement reached in 1996 with affected stakeholders requiring dredging of the lower river has proven ineffective in mitigating the environmental impacts, possibly causing additional acid rock drainage (Townsend and Townsend, 2004). In 1992, the Australian Conservation Foundation reported that the Ok Tedi River up to 70 kilometres from the mine was "almost biologically dead" (Akpan, 1998). In 1999, OTML estimated that dieback of vegetation associated with the tailings could cover up to 1350 square kilometres along the Ok Tedi and Fly Rivers (BHP, 1999). In 2003, the estimate was increased to 2,400 square kilometres of land that has been, or will be, affected (Ok Tedi Mining Limited, 2003). Peak impacts are not likely to occur until 50 years post-mining (Townsend and Townsend, 2004), and it may take centuries for the river system to naturally recover.

Paul Anderson, the CEO of BHP in 2001 stated that, "the mine (Ok Tedi) is not compatible with our environmental values and the Company should not have become involved" (WWF, 2001). In 2001, BHP wrote off their entire investment in the Ok Tedi project to that date (BHP, 1999), approximately A \$97 million after tax (BHP, 2002). A further A\$286 million after tax was written off in June 2001 when BHP transferred its share of assets at Ok Tedi to the PNG Sustainable Development Program Company (BHP, 2002). In addition to writing off assets, BHP agreed to provide a repayable funding facility to the Program Company up to a maximum of US $\$ 100 \mathrm{~m}$ and also to purchase copper concentrate in the event of a drought preventing transport along the river. In 1996, BHP also reached an out-of-court settlement with the landholders of the Lower Ok Tedi, resulting in compensation payments of up to Kina 150 million (approximately A $\$ 50 \mathrm{~m}$ ) (BHP Billiton). As of 2001 when BHP withdrew from the Ok Tedi project, the company's return on investment was a mere US\$66 million (BHP Billiton). BHP Billiton has been released from any liabilities arising from the operation of the mine subsequent to the company's departure. Future dividends from BHP Billiton's transferred 52\% shareholding will be directed to sustainable development programmes. BHP Billiton's involvement in the Ok Tedi mine has therefore cost the company at least A \$330 million and the site' environmental issues remain unchanged.

The acting managing director of OTML in 1999, Bill Blenkhorn, stated that it is "most disappointing that the best solution for the people is worst for the environment and vice-versa," (Anonymous, 1999b). For the last ten years, Ok Tedi has been responsible for $10 \%$ of Papua New Guinea's gross domestic product and for 20\% of PNG's export earnings (Anonymous, 1999a) (compare this with BHP's total contribution to Australia's GDP of $0.76 \%$ (Colley, 2001)). PNG has therefore seen significant economic benefit from the mine and the early closure of the mine was not an economically sustainable solution. The development programmes and trust funds put in place by Ok Tedi Mining Limited contribute to increasing the social sustainability of the mine although it is difficult to ensure the equitable distribution of trust funds to affected peoples. BHP Billiton have now publicly stated that the company "will not commit to a new mining project that disposes of waste rock or tailings into a river," (Rae, 2000): such practice is not environmentally sustainable and may represent a significant future financial liability. As an update, Ok Tedi has reported record profits and now recognises its environmental problems: "We are concerned that OTML's environmental monitoring indicated that environmental impact of the mine may prove to be greater than previously understood.” (Managing Director, Keith Faulkner).

Other examples of direct discharge are the Freeport-McMoran's Grasberg mine across the border from Ok Tedi in the Indonesian province of Papu and Rio Tinto's Lihir mine located on Lihir Island in Papua New Guinea. Lihir utilises submarine tailings disposal discharging into waters of Louise Harbour at a depth of $125 \mathrm{~m}$, at a rate of 8,000 t/day. This contrasts with the direct discharge by Freeport into the Aghawagon River at a rate which was estimated at 220,000 dry metric tonnes per day of fine particles. For a more detailed discussion on Freeport and Lihir refer to Hart and Boger (2005). Before leaving the subject however, the following quote is of interest. "[It’s] equivalent to me pissing in the Arafura Sea." (James R. 
Moffatt, CEO of Freeport-McMoran Copper and Gold, commenting on pollution from his company's operation in West Papua. Ridgeway, 1998, No. 572, \#65). It would seem that such a comment is most inappropriate for such a worldclass industry.

\subsection{Typical practice}

The most common practice in the industry worldwide is to use clarifiers at the end of the process, producing a clear overflow for recycle back into the process and a bottom low-concentration waste product which is pumped to a tailings storage facility. Some of these tailings storage facility can be very large, particularly in the high-throughput activities like copper mining in Chile and in sand mining for oil in the Canadian north.

There are a number of issues associated with tailings storage facility including their tendency to leak or seep and potential for catastrophic failure. From the industry's point of view, tailings storage facility are a method to store waste over a long period of time, thus deferring expenditure in regard to rehabilitation until the end of mining. Herein we believe lies the large attraction of the construction and use of tailings storage facility. In the most simplistic of terms, it would seem to be equivalent to you and I storing the garbage from our homes in our backyard for disposal at some time in the future, perhaps after we had disposed of the home. In fact, this often happens in the industry, where the liability is passed on to the taxpayer at the end of the day. The website www.wise-uranium.org/mdaf.html is a listing of the major failures that have occurred in the last 47 years. On average, there are two to five major failings per year and there have been 42 publicly reported failures in the last twenty years. One of the more publicised failures was the Boliden Dam rupture on 25 April in 1998; five million cubic metres of water and particulates containing high levels of heavy metals poisoned two rivers and flooded crops. A disaster of this order is enough to bankrupt a company. In this case there was a fine of 45 million lira; Boliden was suing the construction company for one million lira; regional authorities sued Boliden for 89.8 million euros; shareholders apparently sued the company for their losses and the company shares plummeted. Clean-up costs apparently were on the order of 250 million euros. There are many other examples of failures, some ending up in extensive loss of human life. The Stava failure in Italy on 19 July 1985 resulted in tailings moving at $90 \mathrm{kph}$, flowing $4.2 \mathrm{~km}$ downstream, killing 268 people, destroying 62 buildings, and cost 155 million lira to clean up. In this instance, ten people were convicted of multiple manslaughter.

Given the risks associated with building and maintaining tailings dams, one cannot help but wonder why one would build dam retaining water-like material instead of moving to techniques which remove a significant amount of water, result in a smaller footprint, and obviously lower the risk associated with tailings disposal. The answer of course is always the same, and that is, economics. The additional up-front capital expenditure is generally deemed undesirable in the industry; this attitude is perpetuated by several factors including accounting practices (discussed below) that allow recognition of rehabilitation costs to be deferred until the end of operations.

\subsection{Paste}

Figure 1 shows a schematic diagram of a measurement of strength, e.g. the yield stress, as a function of concentration for what we might call a typical fine particle waste generated in the minerals industry. There have been numerous attempts to determine what is meant by a paste; suffice to say that those employing tailings dams invariably pump at a concentration below which a yield stress occurs. The so-called method of "thickened tailings" in some quarters simply means that the material has a very low yield stress, say on the order of 1-5 $\mathrm{Pa}$, and is pumped out to a disposal area where it flows out like a river delta and where a significant amount of water is lost due to evaporation. The next region up the graph, let's say with a yield stress of from 30-80 Pa, represents the region in which the alumina industries have operated, where they have made a paste-like material, but the paste-like material they have made in no way represents the "paste" which is used in mine stope backfill, which can have a yield stress certainly in excess of $200 \mathrm{~Pa}$ and possibly as high as $800-1000 \mathrm{~Pa}$. In mine stope backfill the paste is produced often by filtration and mixed with concrete and generally dropped or pumped back into an underground mine to serve as mine stope backfill. There have been great advances made in this area, which is a positive step in regard to more sustainable practices in the industry (Ilgner, 2006). 


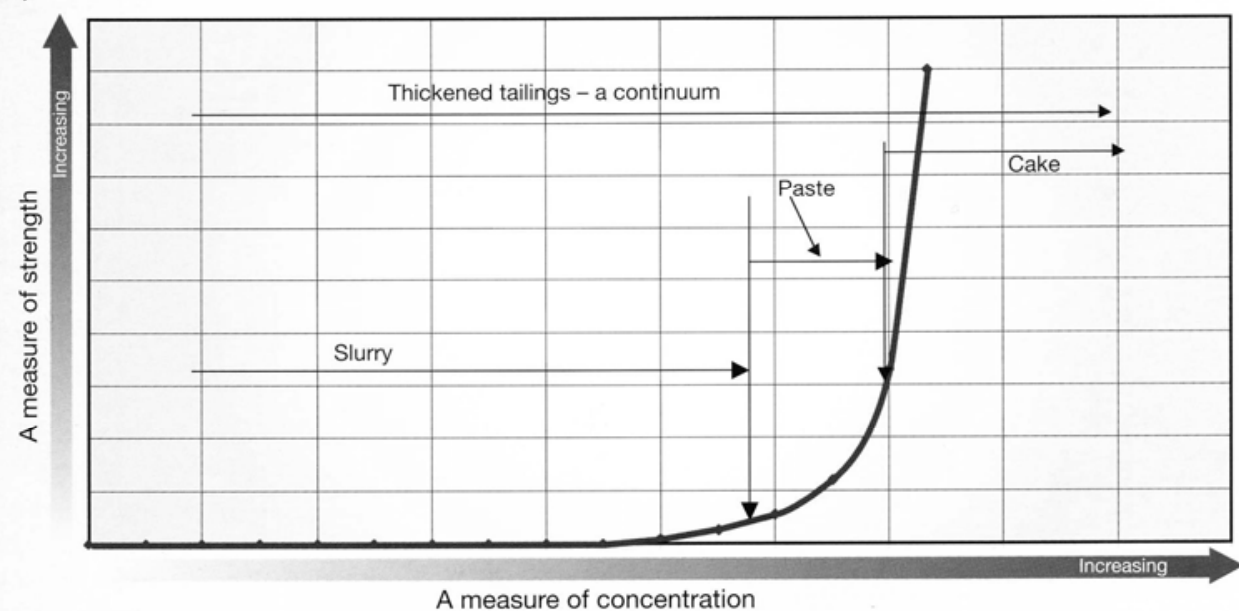

Figure 1 A typical yield stress concentration curve for a tailings suspension (after Jewell and Fourie, 2006)

In summary, since the first seminar associated with paste and thickened tailings, held in Canada in 1999, there have been significant technological advances available for use in the management of tailings waste produced in the minerals industry. There have also been some very significant improvements, particularly in the alumina industry and in a few other areas where thickened and/or paste materials are now produced. Motivation for dewatering is continuing to increase, particularly in countries like Australia, Chile, Botswana and South Africa, where water is becoming a major issue and it would make sense to recover as much water as possible before disposal of the tailings. But, a large part of the industry still continues to pump low density material to very large disposal dams which get bigger and bigger, and not only can present a significant risk, but also at the end of the day represent a very significant cost in terms of rehabilitation. We will now address and ask the question, why? Why hasn't a larger proportion of the industry adopted the technologies that are now available to move from the construction of a conventional tailings storage facility to more sustainable practices?

\section{$3 \quad$ Mandating improved tailings methods}

Historically, industry-wide environmental performance improvements have been achieved through mandating requirements via regulation. However, it is unlikely to be a feasible solution to impose additional regulations mandating the use of a given tailings disposal method. Governments must achieve a balance between effective environmental protection and the costs of such protection, resulting in regulations that are necessarily aimed at the lowest common denominator, defining minimum performance standards. Mandating best practice would likely result in additional regulatory workload further to any companies reluctant to adopt new methods or alter existing practices. Best practice, outcome-based regulations would require overhaul of existing regulatory systems. Required changes to permitting, inspection and monitoring systems to implement such overhaul may fail the cost/benefit criteria of under-resourced regulators.

Nonetheless, some alterations to existing regulatory practices may facilitate or even encourage more widespread implementation of thickened tailings, particularly within the United States where mining and environmental regulations presuppose the use of conventional tailings storages.

Regardless of environmental legal requirements, improved tailings disposal methods would likely be more widely implemented if more managerial emphasis was placed on minimising overall costs rather than on minimising short-term costs. Short-term profit-based managerial mentality must be addressed in order to promote sustainability goals and direct mining company attention to the minimisation of long-term environmental remediation liabilities. Such forces are unlikely to be countered directly through raising environmental performance standards or perpetuating additional international agreements. 


\section{Short-term managerial emphasis}

High-risk management can be defined from two perspectives. In terms of mine waste management, a highrisk manager makes a substantial investment in technology that is not widely accepted as the industry norm, such as thickened tailings disposal, pursuing long-term environmental performance goals, ease of rehabilitation and minimisation of catastrophic failure risk. From another perspective, a high-risk manager selects a conventional tailings dam, effectively wagering the company on the integrity of that dam since the costs of a tailings dam failure may result in bankruptcy or loss of social license to operate. Many of the pressures experienced by the manager when making such decisions stem from the intrinsic structure of capitalist society and conventional modes of doing business.

Despite the potential savings in reclamation and environmental management costs, thickened tailings disposal methods generally require additional initial capital expenditure and are thus disfavoured due to continued managerial emphasis on deferring expenditure. Significant short-term emphasis is generated through corporate culture, remuneration structuring and pressure to maximise shareholder value. Higher profit margins yield capital and increase business value. The time value of money underpins the pressure felt by private enterprise to maximise profits in the short term, to the immediate benefit of shareholders and short-term cultivation of the economy. Higher interest rates intensify such short-term thinking (Eckersley, 2000), promoting deferral of expenditure to reduce borrowings. Emphasis on deferral of expenditure promotes low-capital tailings disposal solutions, with little emphasis on final rehabilitation costs particularly if closure is over twenty years hence.

Further to management mandates to maximise shareholder value, the main vehicle through which management performance is communicated to shareholders is the financial report. Financial reporting practices are seldom contemplated by operational staff at a mine site, yet influence upper management by focusing attention on profit maximisation within the terms of financial information required to be publicly disclosed. Thus, long-term waste management strategies are influenced by whether and how the company must report the associated costs. Financial report information also serves to inform stakeholders; whilst environmental regulation may require that remediation be performed, it is not capable of ensuring a company is sufficiently solvent to be able to afford the planned remediation. Financial reporting requirements therefore have a role to play in increasing stakeholder confidence and promoting accountability through transparent financial information. The reporting requirements developed over the last decade at least require the recognition of long-term liabilities within the company balance sheet, however by permitting those amounts to be discounted future liabilities are underemphasised, perpetuating an emphasis on deferral of expenditure.

\section{Discounting in financial reporting}

There are no international financial reporting requirements tailored specifically to the mining industry despite several unique industry attributes that warrant the development of such requirements, including longterm, large-scale waste management issues. Mining remediation costs are thus reported under generic financial reporting requirements; the two prevalent requirements are the US-based Financial Accounting Standard 143: Accounting for Asset Retirement Obligations (SFAS 143) and the International Accounting Standard 37: Provisions, Contingent Liabilities and Contingent Assets (IAS 37). Both standards require the anticipated future expenditure required to satisfy existing legal liabilities to be recognised within the balance sheet as soon as the liability is incurred, and for the amount to be discounted. Additionally, SFAS 143 requires the estimate to be increased by the theoretical cost of transferring or settling the liability with a third party in order to achieve a purported market value of the liability that is comparable between entities. Further discussion of this undesirable facet of SFAS 143 is beyond the scope of the present paper, which will focus on discounting as the predominant motivation for short-term managerial priorities.

When a liability is discounted, generally the current cost of discharging the liability is inflated using an estimate of inflation rates, yielding the future cost of discharging the liability; the resultant inflated estimate is then discounted back to a present value by reducing the estimate by a percentage or discount rate each year. Thus, over the long time-frames typical of mining ventures, sizeable liabilities are discounted to a relatively negligible amount. The discount rate is generally estimated based on prevailing interest rates for investments of a similar time-frame, such as US Treasury Bond yields; discount rates currently used by 
mining entities for closure and rehabilitation costs range from 7 to $12 \%$. At a $7 \%$ discount rate, a $\$ 1$ million liability is thus discounted to a present value of around \$140,000 over a period of 30 years; at $12 \%$ (Freeport-McMoRan apply a rate of $12.6 \%$ to some of their remediation liabilities (Freeport-McMoRan, 2005)), the same liability is discounted to around $\$ 37,000$. Thus, even though future remediation costs may be substantial, these costs are significantly under-emphasised through discounting procedures. As the mining operation progresses, the estimate must be increased exponentially to reflect the unwinding of the discount due to the passage of time, with most of the liability recognised in the latter years of operation when revenue is generally declining.

Discounting in financial reporting has arisen further to concerns that unlike amounts would otherwise be recorded as like amounts in financial reports, misleading report users. As value-based (rather than costbased) accounting objectives become increasingly prevalent, it has become the prerogative of financial accounting to present simulated market prices in financial reports, employing discounting to estimate the price that the market would place on a given investment opportunity or liability (Lovejoy et al., 1989). It is difficult for the financial report user to correlate the recognised liability with the real, existing liability or total anticipated future liability, limiting the usefulness of the information and the transparency of reporting; indeed, the relevance to the investor of reporting any amount discounted to present value is questionable, since only the investor may calculate a present value figure with any meaning (Peasnell, 1977).

It does not serve society's long-term interests to promote discounting of long-term liabilities; such discounting promotes the accumulation of long-term obligations. The result is the perpetuation of an increasing number of large long-term liabilities since the entities responsible are not and will not be held accountable to those liabilities, via complete balance sheet recognition, for many years to come. Whilst in the short term the economy may be stimulated by ignoring the prospect of these liabilities, within decades many entities will be recognising exponential amounts at the end of operations, a time when income is generally declining. Indeed, the very fact that money is discounted in the future reflects society's attitudes towards future generations: that the future matters less than the present (Jacobs, 1995b). When attempting to incorporate sustainability principles into economic theory, discounting does not seem to be compatible; discounting equates to a bias against future generations, whose interests are discounted to practically nothing over time scales longer than a generation. Discounting is a systematic bias towards short-term profitability at the expense of long-term planning; high discount rates in natural resource accounting lead to faster rates of resource exploitation, leading away from a state of sustainability. Higher discount rates arguably favour projects with short-term rather than long-term benefits despite the long-term costs involved, precluding investment and depleting the inheritance of future generations, although it is possible that decreasing investment may slow development, preserving natural resources (Pearce and Turner, 1990). Current economic principles are based upon maximising utility (efficiency) and do not focus upon minimising future regrets (equity), on the premise that gains or losses experienced in the present matter more than if experienced in the future.

In the absence of any justification by the Financial Accounting Standards Board (FASB) or International Accounting Standards Board (IASB) beyond value-based accounting objectives, discounting was presumably permitted in order to soften the impact of requiring full recognition of future liabilities. It is arguable whom the beneficiaries of this softening are: the entities recognising liabilities in that short-term performance is improved, albeit to the detriment of later-year performance; or perhaps the economy as a whole since all entities with large, long-term liabilities report better financial performance at present than would be the case without discounting liabilities. It appears that discounting is necessary in order for liability recognition requirements to be acceptable to industry and government; standards setters seek to avoid rejection of accounting standards and thus pursue acceptable rather than best practice standards (Henderson et al., 1995). If undiscounted amounts were required to be recognised, the resultant amortisation would reduce the reporting entity's taxable income in the short term and hence reduce government revenue as well as shareholder dividends. Alternative taxation arrangements through royalties or a higher taxation rate could mitigate this effect.

The rationale and continued justification for discounting originates from the concept that a dollar invested today is worth a dollar plus interest in a year's time; cost-benefit analysis compares projects to the base case of simply investing the money in an interest-bearing account over the same period. A discount rate based on the market rate of interest may be used by the mining entity for its own cost-benefit analysis, comparing the 
project to a simple investment of funds in an interest-bearing account over the same time period. To use the same discount rate for public reporting of recognised liabilities is not appropriate unless it occurs concomitantly with a fund set aside by the entity specifically for the accumulation of funds for rehabilitation, earning that rate of interest. If the entity is not in fact earning interest at the discount rate, the discount rate is not relevant and discounting generally results in an understatement of present liabilities; the value of the liability should not be modified through a link to interest rates that are not directly relevant to the liability. This point is further underscored when a higher discount rate correlating to long-term US Treasury bonds continues to be applied to a long-term liability as that liability nears the date of discharge, as occurs under SFAS 143 which does not generally permit changes to the discount rate. Additionally, discounting may only be applied with accuracy when the timing of expenditure is fixed or reliably determinable, both so that the correct discount rate may be applied, and so that the amount is discounted over the correct number of years. It is difficult to determine the appropriate discount rate for a liability expected to be progressively discharged. Thirty year yield data are the longest time horizon made available, yet many tailings impoundments have a significantly longer life expectancy.

\section{Setting aside funds}

An additional issue is that whilst accounting recognition of future costs serves to inform financial report users and results in the allocation of costs over the life of the operation, such recognition does not create or set aside funds or in any way insure or protect the entity or stakeholders (Financial Accounting Standards Board, 1975). A legacy of abandoned mine sites and continuing mining company bankruptcies have created an attitude of distrust amongst communities affected by mining. Mining companies have observed their social license to operate becoming more tenuous; community opposition is now sufficient to prevent a mine from proceeding, as experienced for example by Canadian miner Manhattan Minerals at Tambogrande in Peru (Repetto, 2004).

Financial assurance requirements (also known as environmental sureties or performance guarantees) have arisen as a means of protecting affected communities from clean-up costs, arguably attributable to the lack of transparent, accountable financial reporting procedures that would enable communities to be assured the mining company was making adequate provision for closure. In turn, the perpetuation of a system of financial assurance results in a lack of emphasis on transparent accounting methods, since society (often erroneously) believes it is protected from liabilities. Whilst improved accounting practices could preclude the need for financial assurances, such assurances have become an integral part of current regulations, equal to the purchase price of a social license to operate.

Unfortunately, as currently applied, financial assurance requirements are a disincentive for mining companies to accurately assess and report anticipated closure costs. Furthermore, financial assurance does not equate to financial provision for the mining company to perform reclamation; there is no assurance that the company will not bankrupt, bequeathing any liability in excess of the assurance amount to taxpayers. Current financial assurance mechanisms are expensive and are often insufficient to fund reclamation in the event of operator default. Mining companies could provide further, arguably better assurance that remediation duties will be performed by creating trust funds for use in rehabilitation. Such trust funds could be designed to promote transparency and accountability in harmony with financial reporting requirements.

\section{Common sense accounting}

The aims of financial reporting for future tailings facility closure and remediation costs should be to report an estimate that is relevant, wherein the estimate relates to actual anticipated expenditure; reliable, such that the estimate is able to be verified; understandable in that the estimate is clearly identified within financial reports; and comparable to the extent that similar entities would report a similar figure for a similar obligation. Financial reporting requirements could be combined with requirements for trust funds accruing sufficient funds to perform reclamation, motivating the industry to move to more sustainable practices beyond the construction of a large dam.

We recommend a practice which might go as follows. For a greenfield site in the first instance, it would be necessary to estimate the future cost of closing, reclaiming and perpetual care of the tailings storage facility; future costs are achieved by estimating inflation and applying relevant industry pricing indices. This estimate 
would be made in the first instance by the company and verified by a third party in order to introduce transparency and reliability into future cost estimation. An interest-bearing trust fund should be established, equivalent to the amount required to be invested to yield the future cost of closure, reclamation and postclosure care given the prevailing interest rate. The amount to be recognised as a liability within the company's financial report would thus be equivalent to the trust fund balance, since this equates to the liability discounted at a real, relevant rate. The future cost of closure, rehabilitation and post-closure care should be re-examined annually and again verified by a third party. This cost is likely to change substantially; as we all are aware, the initial design of tailings storage facilities is generally far too small and often needs to be changed after a few years of operation. The trust fund balance is adjusted to reflect changes in the estimate. At the end of operations, a certain amount of cash and the interest on that cash is available for closure, rehabilitation and post-closure care. Deposits should be tax deductible and the interest earned on this account should not be taxed, or should only be taxed when funds are withdrawn.

Whilst many governments provide tax relief for the direct costs of providing financial assurance, there are few tax incentives provided despite the potential taxpayer relief from substantial future costs when mining companies are encouraged to perform reclamation. Tax concessions recognise the double cost imposed on mining companies in funding reclamations, both the direct carrying cost of assurance and of the liability, and the unavailability of assurance or trust funds for productive investment (Miller, 1998). Financial assurance costs are usually required by mining companies to be tax deductible (European Association of Mining Industries Metal Ores \& Industrial Minerals, 2003); indeed, insurance premiums are usually deductible (Miller, 2005). Cash deposits to trust funds are tax deductible in Canada, Japan and South Africa although interest earned is taxable; the Canadian mining industry have long envisioned a cash trust fund with contributions made tax deductible and earnings sheltered from tax (Miller, 1998).

Often a sum has been found to be insufficient for compulsory rehabilitation and continuing maintenance of the facility. Indeed, if operations end prematurely, the trust fund will not have sufficiently accrued to fully fund the required activities. Thus, in addition to the cash and the interest earned over the lifetime of the mining operation, an insurance policy should be taken out to deal with the shortfall should the mining company default and leave the liability to a third party. The involvement of an insurer has the added benefit of a third party with a vested interest in the accurate estimation of future costs, further promoting accountability in the industry.

Setting aside cash on an annual basis, reflecting the cost of closure, rehabilitation and post-closure care of the storage site, plus the interest earned on that money, would be an incentive for management to rethink current practices since there would be added incentive to minimise future liabilities. The interest rate on the trust fund is likely to be significantly lower than the rates applied under current financial reporting requirements, reducing the influence of discounting on managerial attitudes. We also believe this method would go a long way towards reflecting the true cost associated with managing and rehabilitating the waste disposal areas associated with this industry and ensuring industry accountability for environmental liabilities. Additionally, as financial assurance costs climb, it will make more financial sense for funds to be set aside in a trust, rather than for companies to pay non-recoverable assurance premiums for the entire liability.

\section{Conclusion}

It is interesting to contemplate what will motivate change in this industry. Certainly if the suggested accounting practices were adopted, one would see changes in the industry. Likewise, if such practices were required for listing on a stock exchange, one would also see some significant changes. We are less optimistic about changes in disposal strategy taking place as a result of the suggested change in accounting practices than we are to reactions associated with water and the need to recover water, and in fact, the general perception of the public associated with this industry. The industry must become more aware of its image and it needs to be far more visible in regard to its impact and its performance in management of its environmental issues. An attitude towards the industry is perhaps well summed up in the best-selling book 'Collapse' by Gerard Diamond in his chapter on Montana:

“...In Montana as elsewhere, companies that have acquired older mines respond to demands to pay for clean-up in either of two ways. Especially if the company is small, its owners may declare the company bankrupt, in some cases conceal its assets and transfer their business effort to other 
companies or to new companies that do not bear responsibility for clean-up at the old mine. If the company is so large that it cannot claim that it would be bankrupt by clean-up costs the company instead denies its responsibility or else seeks to minimise the costs. In either case, either the mine site or the areas downstream remain toxic, thereby endangering people, or else US Federal Government and Montana State Government (hence, ultimately the taxpayers) pay for the clean-up through Federal super fund or corresponding Montana State fund. Montana is not unique in liability for abandoned mine sites being left to the taxpayer. Do our industries really want to be subsidised by the taxpayer in this way, or are we now in a position to move to more sustainable and responsible management of the waste that we produce."

Paste 2008 here in Botswana is the eleventh meeting of this type, which have now been held in Canada, Australia, Chile, Ireland, South Africa and now of course, Botswana. During the tenure of these meetings we have seen tremendous change in the thinking associated with management of waste produced in the minerals industry. We are no longer tied in to the idea of handling a low concentration suspension; we now have techniques available for compression dewatering to produce paste-like materials; we now have the ability to pump, even with a centrifugal pump, paste-like materials over a great distance. More effectively managing the waste produced in the minerals industry is no longer impeded by technology. In fact, tomorrow we could be dewatering to a greater extent, thus reducing the footprint of the disposal area and in fact re-using water and reagents. Technology, or the lack thereof, is no longer an excuse for not dealing with the waste in a more sustainable way.

The more we examine the waste issue in the minerals industry the more it becomes apparent that the industry really has not dealt effectively with the real costs associated with mining and extraction of mineral resources. Other industries worldwide to a large extent can no longer defer the treatment of their waste to some later time in the future. It seems that it is only a matter of time before our industry will have to deal with the real costs in real time associated with the management and treatment of the vast amount of waste it produces. These meetings have helped immensely in terms of establishing and moving forward with appropriate technology. Where we have failed is involving senior management in this process.

\section{References}

Akpan, G.S. (1998) Transnational Environmental Litigation and Multinational Corporations: A Study of the Ok Tedi Case, In University of Dundee, Centre for Energy, Petroleum and Mineral Law and Policy, Dundee, Scotland, UK, pp. 19.

Anonymous (1999a) Caught between a rock and a hard place - Post-CourierPNG.

Anonymous (1999b) No easy solution to damage - OTML - Post-CourierPNG.

Been, K., Brown, E.T. and Hepworth, N. (2001) Liquefaction potential of paste fill at Neves Corvo mine, Portugal. Transactions of the Institution of Mining and Metallurgy (Section A:Min. Technol.), 111, January-April 2002, p. 47.

BHP (1999) BHP and Ok Tedi Discussion Paper, BHP, Melbourne, Australia, October.

BHP (2002) BHP Billiton Withdraws from Ok Tedi Copper Mine and Establishes Development Fund for Benefit of Papua New Guinea People, BHP Billiton, http://wwwbhpbilliton.com/bb/investorsMedia/news/2002/bhpBilliton WithdrawsFromOkTediCopperMineAndEstablishesDevelopmentFundForBenefitOfPapuaNewGuineaPeople.jsp, last updated 8 February 2002, accessed 24th September 2007.

BHP Billiton Ok Tedi Legal Claims, BHP Billiton, http://basemetals.bhpbilliton.com/okTedi/legalClaims.asp, last updated accessed 11th November 2004.

Boger, D.V., Scales, P.J. and Sofra, F. (2006) Rheological concepts, Paste and Thickened Tailings - A Guide (Second Edition), Jewell and Fourie (eds), Australian Centre for Geomechanics, Perth, Australia, p. 25.

Colley, P. (2001) Political Economy of Mining, In Moving Mountains: Communities Confront Mining and Globalisation, (Evans, G., Goodman, J. and Lansbury, N., (eds)) Mineral Policy Institute, Sydney, pp. 19-36.

Cooling, D.J. (2005) Improving the sustainability of bauxite residue management, PhD Thesis, The University of Melbourne.

Cooling, D.J. (2007) Improving the sustainability of residue management practices - Alcoa World Alumina, Paste 2007 - Proceedings of the Tenth International Seminar on Paste and Thickened Tailings, Fourie, A.B. and Jewell, R.J. (eds), Australian Centre for Geomechanics, Perth, Australia, pp. 3-15.

Eckersley, R. (2000) Disciplining the market, calling in the state, In The Emergence of Ecological Modernisation, Young, S.C. (ed), Routledge, pp. 233-252. 
European Association of Mining Industries Metal Ores \& Industrial Minerals (2003) Discussion Paper on Financial Guarantees - (Euromines) European Association of Mining Industries Metal Ores \& Industrial Metals, Brussels.

Financial Accounting Standards Board (1975) Statement of Financial Accounting Standards No. 5: Accounting for Contingencies - Financial Accounting Foundation, Norwalk, Connecticut.

Financial Accounting Standards Board (2001) Statement of Financial Accounting Standards No. 143: Accounting for Asset Retirement Obligations - Financial Accounting Standards Board, Norwalk, Connecticut.

Freeport-McMoRan (2005) Annual Report, Freeport-McMoRan Copper \& Gold Inc.

Hart, B. and Boger, D.V. (2005) Tailings waste management and the triple bottom line, Paste 2005: Proceedings of the International Seminar on Paste and Thickened Tailings, Jewell, R.J., Barrera, S. (eds), Australian Centre for Geomechanics, Perth, Australia, p. 5.

Henderson, S., Peirson, G. and Coombes, R. (1995) Issues in Financial Accounting, Longman, South Melbourne, Australia.

Ilgner, H. (2006) Mine Backfill, Paste and Thickened Tailings - A Guide (2nd edition), Jewell, R. and Fourie, A.B. (eds), Australian Centre for Geomechanics, Perth, Australia, p.169.

International Accounting Standards Board (1998) IAS 37: Provisions, Contingent Liabilities and Contingent Assets International Accounting Standards Board.

Jacobs, M. (1995b) Sustainability and 'the Market': A Typology of Environmental Economics, In Markets, the State and the Environment, Eckersley, R.(ed) Macmillan Education Australia Pty Ltd, Melbourne, Australia, pp. 46-70.

Jewell, R.J. and Fourie, A.B. (eds) (2006), Paste and Thickened Tailings - A Guide (2nd Edition), Australian Centre for Geomechanics, Perth, Australia, p. 5.

Li, T., Singh, U., Coxon, J., Grice, T. and Sainsbury, D. (2003) Development and application of paste fill using dry tailings. International Seminar on Paste and Thickened Tailings, Australian Centre for Geomechanics, Melbourne, Australia, March.

Lord, E.R. (2002) Private communication, Syncrude, Alberta, Canada.

Lovejoy, C., Peasnell, K., Taylor, P. and Talukdar, Y. (1989) Discounting in Corporate Financial Reporting, Institute of Chartered Accountants in England and Wales.

Miller, C.G. (1998) Use of Financial Surety for Environmental Purposes, International Council on Metals and the Environment, Ottawa, Canada, October.

Miller, C.G. (2005) Financial Assurance for Mine Closure and Reclamation - International Council on Mining and Metals, London.

Mineral Policy Institute and AID/WATCH (1999) Putting the ETHIC into E.F.I.C., Mineral Policy Institute \& AID/WATCH, Sydney, Australia.

Ok Tedi Mining Limited (2003) 2003 Annual Review, Ok Tedi Mining Limited, Tabubil, Papua New Guinea, December.

Pashias, N., Boger, D.V., Summers, J. and Glenister, D.J. (1996) A fifty cent rheometer for yield stress measurement. Journal of Rheology 40(6), pp. 1179-1189.

Pearce, D.W. and Turner, R.K. (1990) Economics of Natural Resources and the Environment, Harvester Wheatsheaf, Hertfordshire, UK.

Peasnell, K. (1977) The Present Value Concept in Financial Reporting, Journal of Business Finance \& Accounting, 4(2) pp. 153-168.

Rae, M. (2000) Riverine Tailings Disposal: A Methodology Well Past Its Use By Date, Groundwork, 3 (4).

Repetto, R. (2004) Silence is Golden, Leaden and Copper: Disclosure of Material Environmental Information in the Hard Rock Mining Industry - Yale School of Forestry and Environmental Studies.

Tacey, W. and Hart, B. (2006) Making tailings disposal sustainable: A key business issue, Paste and Thickened Tailings - A Guide (2nd edition), Jewell, R.J. and Fourie, A.B. (eds), Australian Centre for Geomechanics, Perth, Australia, p. 13.

Townsend, P.K. and Townsend, W.H. (2004) Assessing an Assessment: The Ok Tedi Mine, In Bridging Scales and Epistemologies: Linking Local Knowledge and Global Science in Multi-Scale Assessments, Alexandria, Egypt, 17-20 March.

Vietti, A.L. and Coghill, M. (2006) Slurry Chemistry, Paste and Thickened Tailings - A Guide (2nd edition), Jewell, R.J. and Fourie, A.B. (eds), Australian Centre for Geomechanics, Perth, Australia, p. 189.

Wood, I., Murray, G. and Hood, A. (2001) Riverine Tailings Disposal From a Company's Perspective, Groundwork, $4(1)$.

WWF (2001) Ore or Overburden II; WWF's 2nd Annual Scorecard on Australian Mining Company Environmental Reports, Groundwork, 4 (1). 